\title{
Rancang Bangun Alat Pengirim Sinyal Arus 4-20 mA dari Pemancar Suhu melalui Jaringan GPRS
}

\author{
TRIYAN WAHYU NUGROHO, ASNIAR ALIYU, JOKO PRASOJO
}

Sekolah Tinggi Teknologi Nasional Yogyakarta

Email: triyan.wn@gmail.com

\begin{abstract}
ABSTRAK
Peralatan pengendalian proses dan akuisisi data pada industri migas umumnya menggunakan sinyal arus 4-20 mA. Masing-masing peralatan membutuhkan media untuk menyalurkan sinyal yang dihasilkan. Tujuan penelitian adalah mengimplementasikan suatu perangkat dengan tiga kanal masukan dan luaran untuk pengiriman sinyal arus 4-20 mA dan akuisisi data dari pemancar suhu pada jarak yang jauh. Pembacaan masukan sinyal arus menggunakan ADC pada mikrokontroler dan transmisi data menggunakan jaringan Internet melalui modul GPRS. Data yang diterima diubah menjadi sinyal arus dengan fasilitas PWM dan rangkaian pengubah tegangan ke arus. Sistem akuisisi data menggunakan aplikasi web.. Berdasarkan hasil pengujian alat didapatkan bahwa sinyal arus 4$20 \mathrm{~mA}$ dari pemancar suhu dengan jangkauan 0-100 ${ }^{\circ} \mathrm{C}$ dan 0-150 ${ }^{\circ} \mathrm{C}$ dapat dikirimkan melalui jaringan GPRS dengan jeda waktu antara 4-17 detik, dengan 2,5625\% span nilai akurasi alat, 1,3\% span nilai kelinieran alat, dan 1,4287\% span nilai presisi alat pada pengujian dengan sampel suhu $27^{\circ} \mathrm{C}$ dan $97^{\circ} \mathrm{C}$.
\end{abstract}

Kata kunci: sinyal arus, pemancar suhu, GPRS.

\begin{abstract}
Controlling process and data acquisition tools in the oil and gas industry generally uses 4-20 mA of current signal. Each tools is requiring the media to transmit the signal that was resulted. The aim of this research is to implement a device equipped by three input and output channels for sending a 4-20 mA current signal and data acquisition from the temperature transmitter at a distance away. Reading of the input current signal is using the ADC on a microcontroller while data transmission is using the Internet network through GPRS module. That the data received is converted into a current signal by PWM facilities and a voltage to current converter circuit. Data acquisition system is using a web application. On testing tool got the result that the current signal of 4-20 mA transmitter with a temperature range of $0-100{ }^{\circ} \mathrm{C}$ and $0-150^{\circ} \mathrm{C}$ can be transmitted over the GPRS network with a time delay between 4-17 seconds with $2.5625 \%$ span of the accuracy values, $1.3 \%$ span of linearity values, and $1,4287 \%$ span of precision values tools on testing with a sample temperature of $27^{\circ} \mathrm{C}$ and $97^{\circ} \mathrm{C}$.
\end{abstract}

Keywords: signal flow, temperature transmitters, GPRS. 


\section{PENDAHULUAN}

Proses produksi yang kompleks di industri pada umumnya menggunakan sistem pengukuran dan pengendalian secara otomatis dengan peralatan pengendali elektronik berbasis komputer seperti Pengendali Logika Terprogram (Programmable Logic Controller, PLC) atau Sistem Pengendali Terdistribusi (Distributed Control System, DCS). Sistem pengukuran dan pengendalian secara elektronik ini mendapat masukan dari pemancar elektronik (electronic transmitter) yang terpasang di lapangan. Sinyal luaran dari pemancar elektronik yang umum digunakan di industri adalah sinyal arus standar 4-20 mA.

Transmisi sinyal arus tidak terlalu terpengaruh oleh panjang kabel, namun untuk jarak yang cukup jauh, penggunaan kabel sebagai media transmisi menjadi kurang ekonomis. Untuk mengatasi permasalahan ini, digunakan media nirkabel berupa gelombang radio, dengan jarak yang bisa dicapai sejauh $500 \mathrm{~m}$ hingga $5 \mathrm{~km}$. Jangkauan jarak gelombang radio dirasa kurang mencukupi untuk industri yang lokasi produksinya tersebar dengan jarak yang sangat jauh.

Pada sistem pengukuran dan pengendalian industri yang sangat kompleks dan terpisah oleh jarak yang sangat jauh, misalnya di lapangan migas lepas pantai, dimana lokasi sumur dan proses produksi berada sangat jauh dari ruang pengendali, dibutuhkan media pengiriman sinyal yang bisa mengirimkan sinyal arus 4-20 mA pada jarak yang sangat jauh.

Beberapa penelitian mengenai sinyal arus 4-20 mA telah dilakukan oleh Hengky Ardianto mahasiswa Universitas Petra Surabaya dengan judul penelitian "Perencanaan dan Pembuatan Pengatur Arus 4-20 mA DC dengan Mikrokontroler 8031 untuk Beban Maksimum 300 Ohm" (Ardianto, 1998). Pada tahun 2008, Timothy Joy Siswanto mahasiswa Universitas Petra Surabaya juga meneliti tema yang sama dengan judul "Perancangan Modul Akuisisi Data dengan Input Output Digital dan Analog", yang menggunakan sinyal arus 4-20 $\mathrm{mA}$ sebagai masukan (Siswanto, 2008). Penelitian yang melibatkan transmisi sinyal melalui jaringan GPRS antara lain dilakukan oleh Pathoni seorang mahasiswa Universitas Komputer Indonesia Bandung, pada tahun 2009 meneliti tentang "Pengiriman Data Pengukuran Otomatis Menggunakan Teknologi GPRS" (Pathoni, 2009).

Penelitian ini mengkaji mengenai perancangan alat pengirim sinyal arus 4-20 mA dari pemancar suhu pada jarak yang sangat jauh melalui jaringan GPRS. Selain diaplikasikan di industri migas, diharapkan hasil penelitian ini juga dapat diaplikasikan di industri secara umum untuk transmisi sinyal arus 4-20 mA dalam sistem pengukuran dan pengendalian yang membutuhkan jarak yang sangat jauh.

\subsection{Pemancar suhu}

Sebuah pemancar suhu terdiri atas RTD (Resistive Temperature Detector) sebagai sensor suhu yang luarannya diolah oleh rangkaian pengolah sinyal sehingga menghasilkan luaran berupa sinyal arus 4-20 mA yang besarnya sebanding dengan suhu yang diukur.

Pada sebuah pemancar suhu, sinyal luaran berupa sinyal arus 4-20 mA didapatkan dengan menggunakan rangkaian pengkondisi sinyal berupa Konverter Analog ke Digital (Analog to Digital Converter, $A D C$ ). Nilai digital yang dihasilkan melalui ADC akan dibaca oleh mikrokontroler dan dikoreksi berdasarkan hasil kalibrasi dari manufaktur untuk mendapatkan hasil pembacaan yang akurat. Nilai hasil koreksi akan dikonversi menjadi sinyal analog dengan menggunakan Konverter Digital ke Analog (Digital to Analog Converter, DAC), dan 
dihasilkan sinyal arus 4-20 mA yang besarnya sebanding dengan suhu yang dibaca oleh sensor RTD. Diagram kotak untuk rangkaian ini ditunjukkan pada Gambar 1.

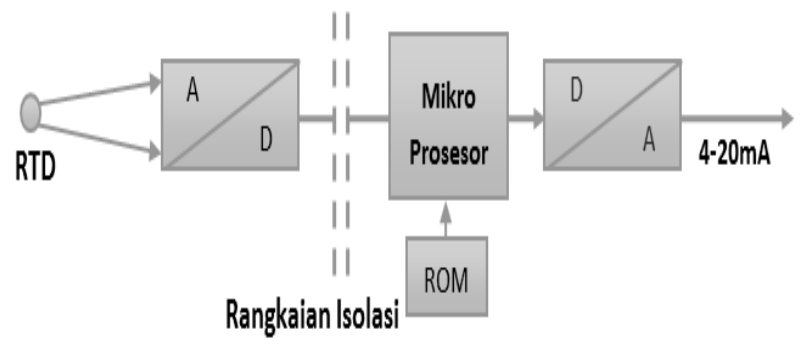

Gambar 1. Diagram kotak pemancar suhu

\subsection{Sinyal arus 4-20 mA pada sisteminstrumentasi di industri}

Sinyal arus 4-20 mA sebagai standar sinyal komunikasi untuk instrumentasi dalam industri diatur dalam dokumen IEC 60381 dan ANSI/ISA-S50.1-1982.

Sinyal arus lebih banyak digunakan daripada sinyal tegangan pada sistem pengukuran dan pengendalian di industri, karena sinyal arus memiliki beberapa keunggulan, antara lain lebih tahan terhadap derau (noise), dapat ditransmisikan pada jarak yang jauh dan tidak terpengaruh terhadap resistansi kabel, serta mampu mengenali masalah seperti putusnya koneksi ataupun hubung singkat (short circuit).

Hubungan antara kondisi proses dengan luaran pemancar elektronik ditunjukkan dalam Gambar 2. Nilai $4 \mathrm{~mA}$ merepresentasikan nilai $0 \%$ dari skala pengukuran, $20 \mathrm{~mA}$ merepresentasikan nilai $100 \%$ dari skala pengukuran, dan nilai diantara 4-20 mA merupakan nilai interpolasi $0-100 \%$ dari skala pengukuran.

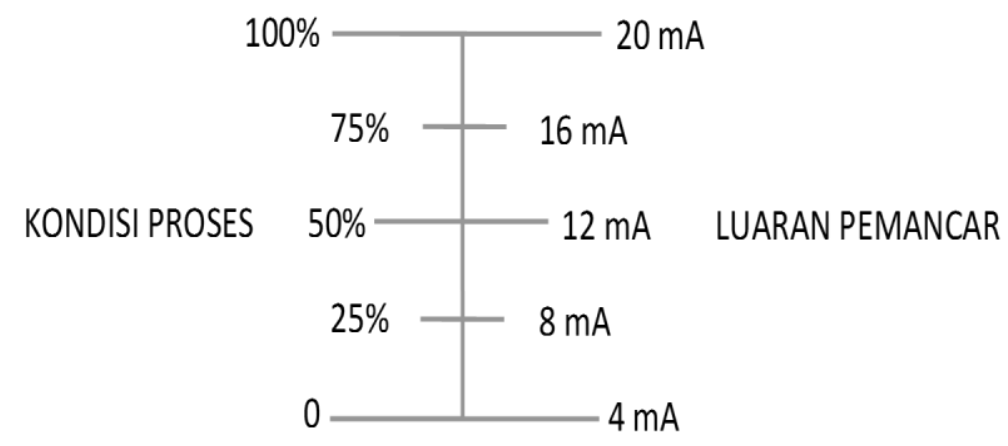

\section{Gambar 2. Hubungan kondisi proses dengan luaran pemancar}

Hubungan antara kondisi proses dengan luaran pemancar secara umum dapat dinyatakan dalam Persamaan (1).

$$
C=m P+b
$$

Dengan $C$ adalah arus dalam $\mathrm{mA}, P$ adalah persentase sinyal proses, $m$ adalah rentang sinyal (span), dan $b$ adalah nilai bawah (zero) dari rentang sinyal. Rentang sinyal adalah selisih 
besaran sinyal dari nilai atas (kondisi proses 100\%) dan nilai bawah (kondisi proses 0\%). (Kuphaldt, 2015)

Pada sinyal arus 4-20 mA, nilai bawah $(b)$ adalah $4 \mathrm{~mA}$, dan rentang sinyal $(m)$ adalah 16 $\mathrm{mA}$, sehingga Persamaan (1) dapat dinyatakan dalam bentuk Persamaan (2).

$$
C=16\left(\frac{P}{100 \%}\right)+4
$$

Apabila diketahui nilai arus luaran pemancar, maka untuk mendapatkan hasil pengukuran yang sesungguhnya, digunakan Persamaan (3).

$$
P=P_{L}\left[\frac{C-4}{16} \times\left(P_{H}-P_{L}\right)\right]
$$

dengan $P$ adalah nilai hasil pengukuran yang sesungguhnya, $C$ adalah arus luaran dari pemancar, $P_{L}$ adalah batas bawah nilai pengukuran yang diwakili oleh sinyal arus $4 \mathrm{~mA}$, dan $P_{H}$ adalah batas atas nilai pengukuran yang diwakili oleh sinyal arus $20 \mathrm{~mA}$.

Keandalan sebuah peralatan instrumentasi dengan luaran arus 4-20 mA dapat ditentukan dari beberapa karakteristik yang dimilikinya, antara lain ketelitian (accuracy), kelinieran (linearity), dan presisi (repeatability).

\subsection{Komunikasi data melalui GPRS}

GPRS merupakan sistem transmisi berbasis paket untuk GSM yang menggunakan prinsip "tunneling". GPRS menawarkan laju data sampai 160 kbps. Kanal-kanal radio ganda dapat dialokasikan bagi seorang pengguna dan kanal yang sama dapat pula digunakan secara berbagi (sharing) di antara beberapa pengguna sehingga menjadi efisien. GPRS menggunakan teknologi tersakelar paket (packet switching) yang memungkinkan semua pengguna di dalam sebuah sel dapat berbagi sumber-sumber yang sama, dengan kata lain pelanggan menggunakan spektrum radio hanya ketika benar-benar mentransmisikan data. Pentarifan biaya mengacu pada volume penggunaan. Pengguna ditarik biaya dalam kaitannya dengan banyaknya data yang ditransmisikan, sehingga layanan ini cocok digunakan untuk akses Internet (Pathoni, 2008).

Diagram kotak modul GPRS ditampilkan pada Gambar 3. Modul ini adalah sebuah modul elektronik yang memungkinkan peralatan berbasis mikrokontroler atau komputer mengirimkan dan menerima data melalui jaringan GSM dan GPRS. Pengendalian dan konfigurasi modul GPRS dilakukan menggunakan komunikasi serial, dengan perintah yang disebut perintah AT (AT Command). Setiap modul GPRS dilengkapi dengan kode IMEI (International Mobile Station Equipment Identity) yang unik sebagai tanda pengenal sebuah modul GPRS pada jaringan GSM. 


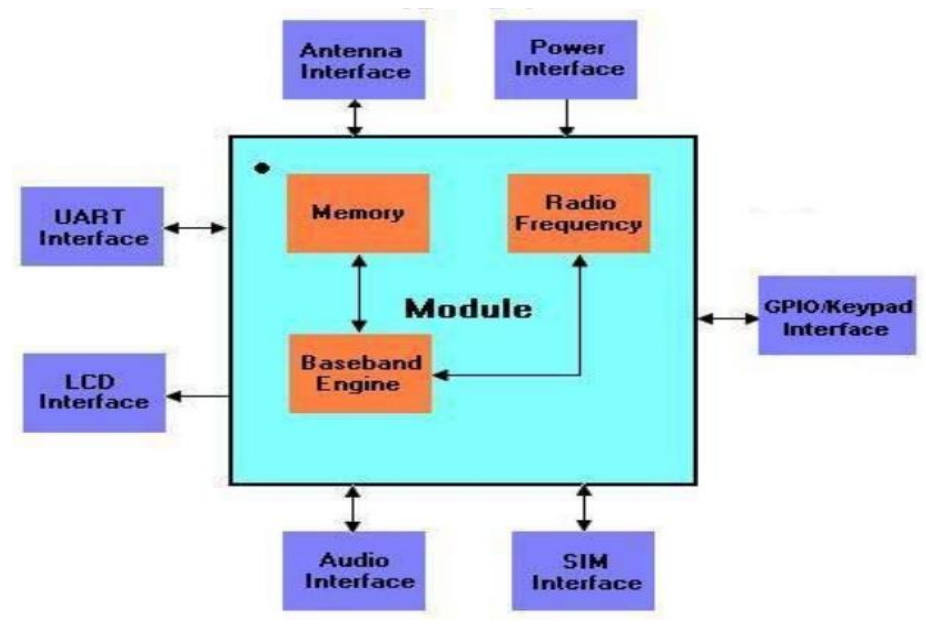

Gambar 3. Diagram kotak modul GPRS

\subsection{Aplikasi web}

Aplikasi web (web application) adalah suatu aplikasi yang diakses menggunakan penjelajah web (web browser) melalui suatu jaringan seperti Internet atau intranet. Aplikasi web merupakan suatu aplikasi perangkat-lunak komputer yang dikodekan dalam bahasa yang didukung penjelajah web (seperti HTML, JavaScript, AJAX, Java) dan bergantung pada penjelajah tersebut untuk menampilkan aplikasi.

Sebuah aplikasi web umumnya terdiri dari program-program script yang dieksekusi di server (server side scripting) seperti PHP, Python, Perl, dan sebagainya yang mengakses suatu basis-data untuk diolah dan menghasilkan tampilan halaman web dalam bahasa HTML (Hypertext Markup Language) pada penjelajah web di sisi klien. Untuk mendukung interaktivitas, digunakan bahasa pemrograman JavaScript yang menjadikan tampilan halaman web menjadi lebih dinamis. Diagram kotak sebuah aplikasi web ditunjukkan pada Gambar 4.

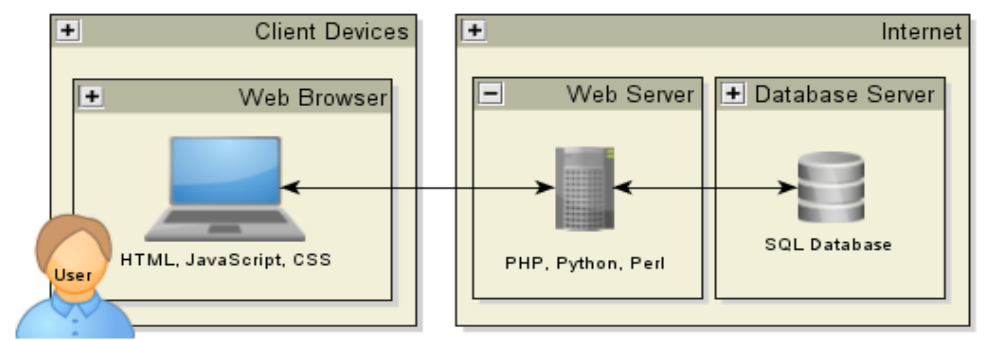

Gambar 4. Diagram kotak aplikasi web

\section{METODOLOGI PENELITIAN}

Alat ini dirancang sedemikian rupa sehingga satu alat bisa difungsikan sebagai pengirim maupun penerima sinyal. Pemilihan fungsi alat sebagai pengirim atau penerima dilakukan melalui menu pengaturan di layar LCD pada saat alat pertama kali dinyalakan.

Pada alat pengirim dan penerima masing-masing disediakan 3 kanal masukan dan luaran yang masing-masing dapat dikonfigurasi nilai batas bawah, batas atas, dan satuan dari besaran yang diukur. Diagram kotak sistem secara umum ditunjukkan pada Gambar 5. 


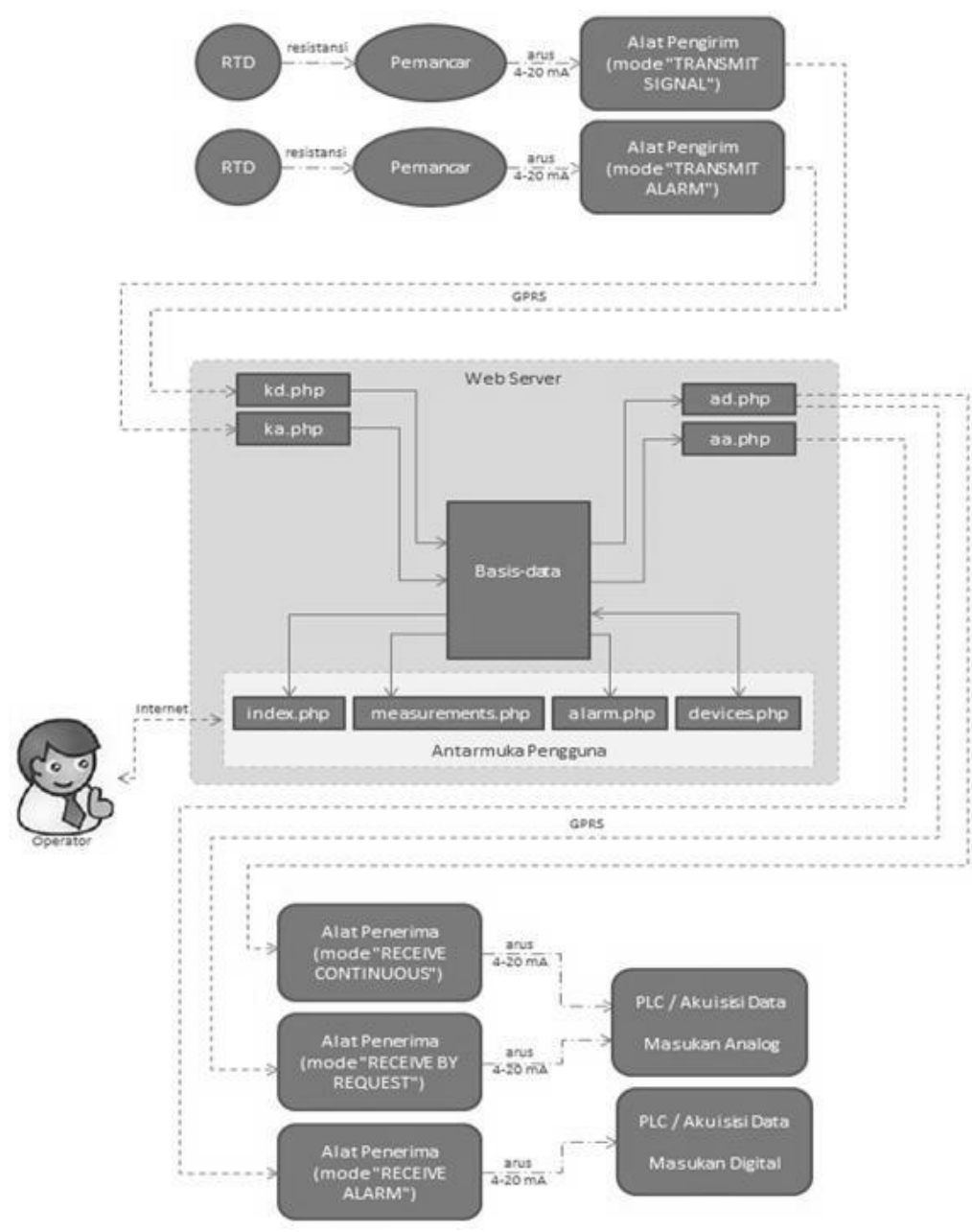

Gambar 5. Diagram kotak sistem

Pemancar suhu terhubung dengan alat pengirim di lapangan. Alat pengirim akan membaca sinyal arus 4-20 mA luaran dari pemancar suhu, dan mengubahnya menjadi data digital. Data digital dikirimkan ke aplikai web di Internet untuk disimpan di dalam basis-data. Alat penerima yang berada di ruang pengendali akan mengambil data terakhir yang disimpan di dalam basis-data, dan mengubahnya kembali menjadi sinyal arus 4-20 mA. Sinyal arus ini menjadi masukan bagi alat pengendali atau akuisisi data.

\subsection{Perancangan perangkat-keras}

Perangkat-keras dirancang sedemikian rupa sehingga satu alat bisa difungsikan sebagai pengirim maupun penerima sinyal. Pada alat pengirim dan penerima masing-masing disediakan 3 kanal masukan dan luaran yang dapat dikonfigurasi nilai batas bawah, batas atas, dan satuan dari besaran yang diukur. Pada menu pengaturan juga disediakan pilihan mode transmisi sinyal yang diinginkan, yaitu transmisi sinyal secara kontinu, berdasarkan permintaan, atau hanya jika ada alarm. Pemilihan cara transmisi sinyal dilakukan melalui menu konfigurasi. Perancangan pilihan cara transmisi sinyal disajikan pada Tabel 1. 
Tabel 1. Pilihan cara transmisi sinyal

\begin{tabular}{|c|c|c|}
\hline Alat Pengirim & Alat Penerima & Keterangan \\
\hline \multirow[t]{2}{*}{$\begin{array}{l}\text { TRANSMIT } \\
\text { SIGNAL }\end{array}$} & $\begin{array}{l}\text { RECEIVE } \\
\text { CONTINUOUS }\end{array}$ & $\begin{array}{l}\text { - Alat pengirim akan terus menerus membaca } \\
\text { sinyal masukan, dan mengirimkannya ke aplikasi } \\
\text { web. } \\
\text { - Alat penerima akan secara terus menerus } \\
\text { mengambil data terbaru dari aplikasi web, dan } \\
\text { mengeluarkan sinyal melalui luaran analog. }\end{array}$ \\
\hline & \begin{tabular}{ll|} 
RECEIVE & $B Y$ \\
REQUEST &
\end{tabular} & $\begin{array}{l}\text { - Alat pengirim akan secara terus menerus } \\
\text { membaca sinyal masukan, dan mengirimkannya } \\
\text { ke aplikasi web untuk keperluan akuisisi data. } \\
\text { - Alat penerima akan memantau adanya } \\
\text { permintaan data dari pengguna. Jika ada } \\
\text { permintaan data, maka alat akan mengambil } \\
\text { data terbaru dari aplikasi web, dan } \\
\text { mengeluarkan sinyal melalui luaran analog. }\end{array}$ \\
\hline $\begin{array}{l}\text { TRANSMIT } \\
A L A R M\end{array}$ & RECEIVE ALARM & $\begin{array}{l}\text { - Alat pengirim akan secara terus menerus } \\
\text { membaca sinyal masukan, } \\
\text { membandingkannya dengan nilai alarm. Jika } \\
\text { sinyal masukan berada di luar rentang alarm, } \\
\text { maka alat akan mengirimkan data alarm ke } \\
\text { aplikasi web. } \\
\text { - Alat penerima akan memantau data alarm dari } \\
\text { aplikasi web. Jika terdapat data alarm, maka } \\
\text { alat akan mengaktifkan kaki luaran digital yang } \\
\text { sesuai. }\end{array}$ \\
\hline
\end{tabular}

\subsubsection{Rangkaian pengendali}

Rangkaian pengendali pada alat yang akan dibuat dirancang dengan menggunakan Arduino Uno. Arduino Uno adalah sebuah sistem minimum berbasis mikrokontroler ATmega328 yang terdiri dari mikrokontroler, konektor masukan dan luaran, rangkaian catu daya, dan rangkaian komunikasi USB (Universal Serial Bus) untuk berkomunikasi dengan komputer (Agung, 2014).

\subsubsection{Rangkaian masukan analog}

Sebagai rangkaian masukan, digunakan rangkaian dengan resistor $250 \Omega$ untuk mengkonversi sinyal arus 4-20 mA menjadi sinyal tegangan 1-5 V.

Tegangan akan dibaca oleh mikrokontroler melalui masukan analog dan dikonversi menjadi data digital dengan menggunakan ADC. Untuk mendapatkan nilai sinyal arus masukan, digunakan persamaan berikut.

$$
I=\frac{1000 \times N_{A D C} \times \frac{5}{1023}}{250}
$$

dengan I adalah nilai arus masukan dalam $\mathrm{mA}$, dan $\mathrm{N}_{\mathrm{ADC}}$ adalah nilai digital hasil pembacaan tegangan masukan yang telah dikonversi oleh fasilitas ADC (Analog to Digital Converter) pada mikrokontroler.

Nilai pengukuran yang sesungguhnya dapat dihitung dengan menggunakan persamaan berikut. 


$$
P=P_{L}\left[\frac{I-4}{16} \times\left(P_{H}-P_{L}\right)\right]
$$

dengan $P$ adalah nilai hasil pengukuran yang sesungguhnya, $P_{L}$ adalah batas bawah nilai pengukuran yang diwakili oleh sinyal arus $4 \mathrm{~mA}$, dan $P_{H}$ adalah batas atas nilai pengukuran yang diwakili oleh sinyal arus $20 \mathrm{~mA}$.

\subsubsection{Rangkaian peraga dan tombol}

Rangkaian peraga dan masukan tombol dirancang menggunakan modul LCD Keypad, yang terdiri dari layar LCD (Liquid Crystal Display) 16 kolom $\times 2$ baris dan 6 buah tombol tekan (SELECT, LEFT, RIGHT, UP, DOWN, RESET). Tersedia satu buah potensiometer untuk mengatur tingkat kecerahan layar LCD.

\subsubsection{Rangkaian modul GPRS}

Modul GPRS digunakan untuk mengirim data dari alat pengirim ke aplikasi web yang ada di Internet, dan untuk mengambil data dari aplikasi web ke alat penerima. Pada penelitian ini digunakan modul GPRS berbasis IC SIM900.

\subsubsection{Rangkaian luaran analog}

Data yang diterima dari aplikasi web dikeluarkan menjadi sinyal analog oleh mikrokontroler melalui luaran PWM. Sinyal ini berupa tegangan 1-5 V yang akan dikonversi kembali menjadi sinyal arus 4-20 mA menggunakan IC XTR111. IC XTR111 adalah komponen yang berfungsi sebagai sumber arus pada sebuah pemancar elektronik, yang mampu menghasilkan arus luaran 0-36 mA yang proporsional dengan tegangan yang diberikan pada masukan $\mathrm{V}_{\mathrm{IN}}$. Pada penelitian ini XTR111 digunakan sebagai pembangkit sinyal arus 4-20 mA. Rangkaian luaran analog untuk satu kanal yang menggunakan IC XTR111 sebagai pembangkit sinyal arus ditunjukkan dalam Gambar 6.

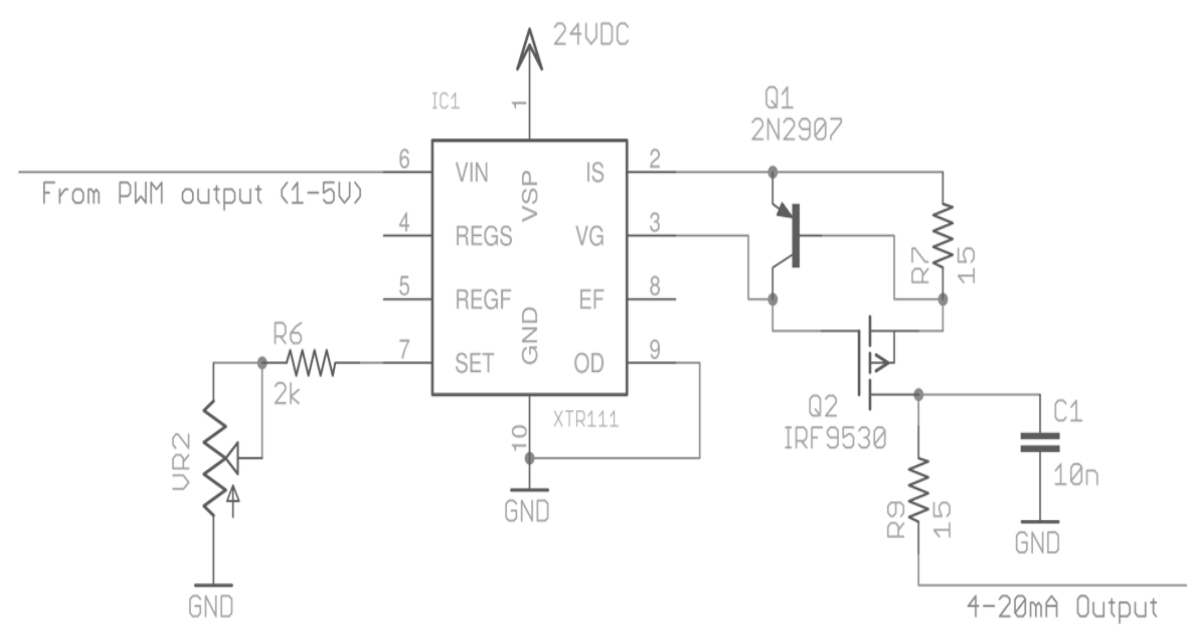

Gambar 6. Rangkaian luaran analog untuk satu kanal

Besarnya arus luaran ditentukan oleh besarnya tegangan masukan ( $\left.\mathrm{V}_{\mathrm{IN}}\right)$, dan rasio antara arus luaran dan tegangan masukan ditentukan oleh resistor $\mathrm{R}_{\mathrm{SET}}$. 


\subsubsection{Rangkaian luaran digital}

Rangkaian luaran digital menggunakan papan sirkuit modul relai dengan tegangan kerja $5 \mathrm{~V}$. Relai ini akan aktif jika terdapat kondisi alarm pada kanal yang bersangkutan. Relai ini akan aktif jika terdapat kondisi alarm pada kanal yang bersangkutan. Rangkaian luaran digital untuk satu kanal ditunjukkan pada Gambar 7.
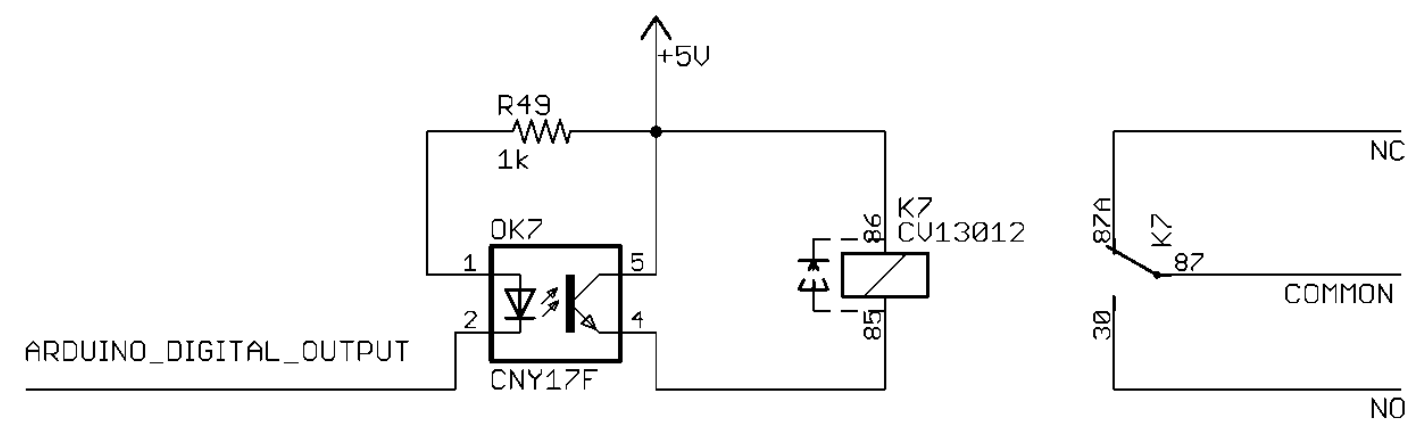

\section{Gambar 7. Rangkaian luaran digital}

\subsection{Perancangan perangkat-lunak}

Perancangan perangkat-lunak terdiri atas perancangan basis-data dan perancangan aplikasi web.

\subsubsection{Perancangan basis-data}

Data hasil pengukuran dan konfigurasi alat disimpan dalam beberapa tabel pada sebuah basis-data MySQL. Hubungan antar tabel di dalam basis-data ditunjukkan pada Gambar 8.

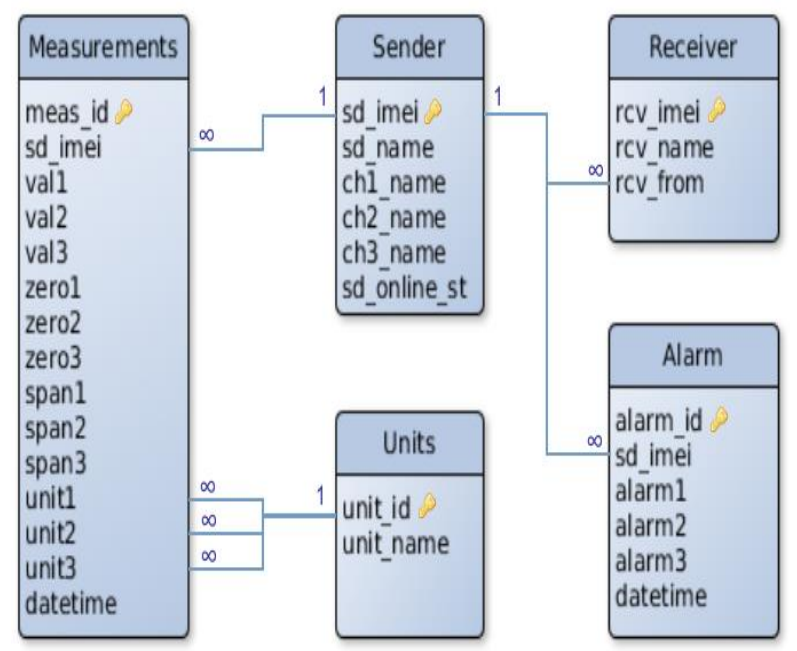

Gambar 8. Hubungan antar tabel di dalam basis-data

\subsubsection{Perancangan aplikasi web}

Aplikasi web terdiri dari beberapa berkas yang berfungsi sebagai penyimpan dan penyedia data, serta sebagai antarmuka bagi pengguna. Berkas-berkas tersebut sebagai berikut. 
1. kd.php untuk menyimpan data hasil pengukuran dari alat pengirim.

2. ka.php untuk menyimpan data alarm dari alat pengirim.

3. ad.php sebagai penyedia data pengukuran terbaru bagi alat penerima.

4. aa.php sebagai penyedia data alarm terbaru bagi alat penerima.

5. index.php menampilkan data hasil pengukuran dan alarm secara waktu-nyata (realtime).

6. measurements.php menampilkan data hasil pengukuran dalam bentuk grafik.

7. alarm.php menampilkan data alarm yang aktif.

8. devices.php digunakan untuk melakukan penamaan alat dan mengatur hubungan antar alat.

Contoh tampilan aplikasi web ditunjukkan pada Gambar 9.

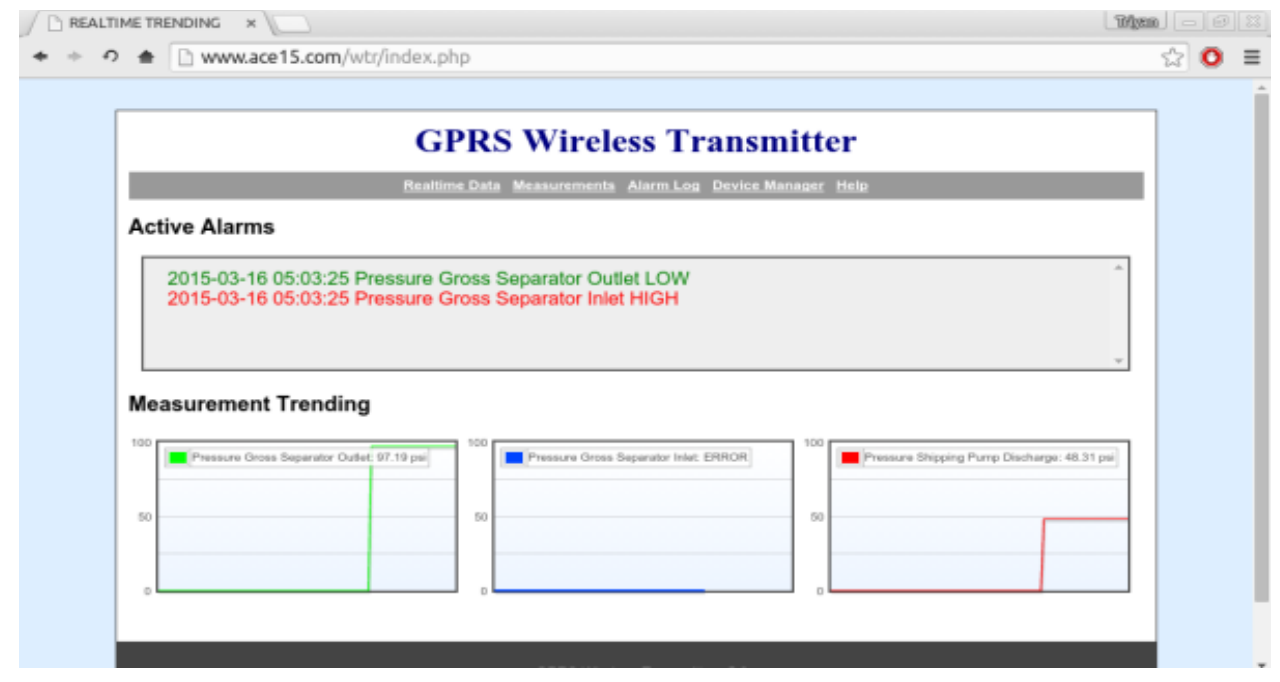

Gambar 9. Tampilan aplikasi web

\section{HASIL DAN PEMBAHASAN}

Pengujian terhadap hasil rancangan dilakukan dengan memberikan masukan pada pemancar suhu dengan jangkauan $0-150{ }^{\circ} \mathrm{C}$ pada kanal 1 dan kanal 2, dan pemancar suhu dengan jangkauan $0-100{ }^{\circ} \mathrm{C}$ pada kanal 3. Pengujian fungsi alat dilakukan pada berbagai mode pengiriman sinyal, dan pengujian karakteristik alat meliputi pengujian akurasi, kelinieran dan presisi.

\subsection{Hasil Pengujian fungsi pengiriman sinyal}

Berdasarkan pada hasil pengujian pengiriman sinyal secara kontinu, alat pengirim mampu mengirimkan data hasil pengiriman dan alat penerima mampu menghasilkan sinyal arus sesuai dengan data yang dikirimkan oleh alat pengirim. Waktu yang dibutuhkan untuk pengiriman sinyal berkisar antara 4,3 - 8 detik. Grafik luaran arus terhadap temperatur pada pengujian pengiriman sinyal kontinyu ditunjukkan pada Gambar 10. Rata-rata galat pada pengujian ini adalah $1,144 \%$ span. 


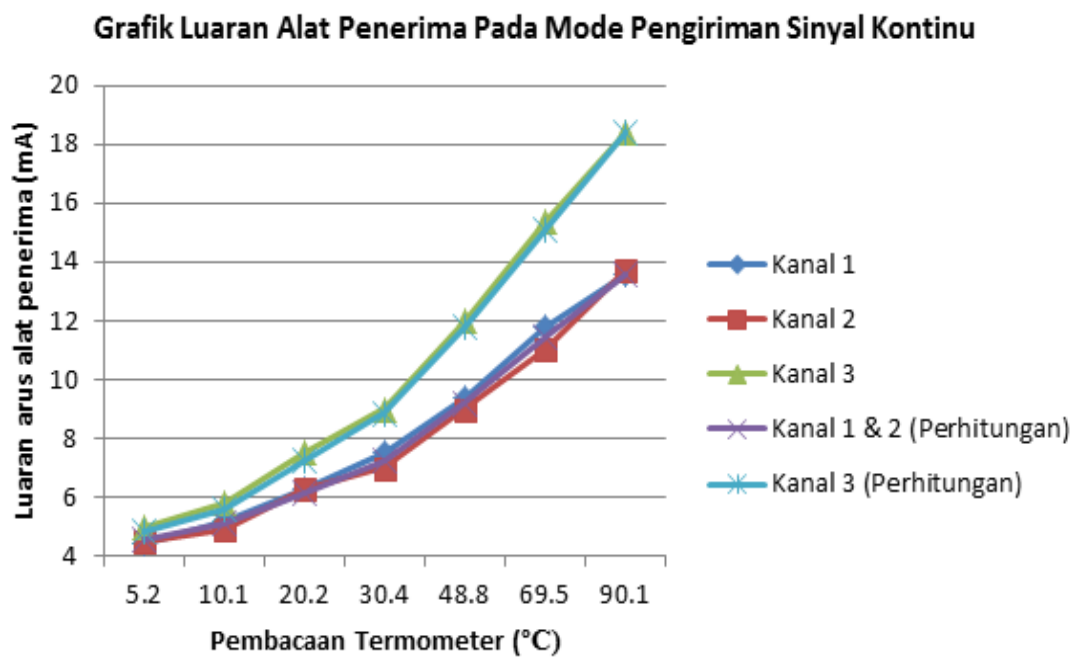

\section{Gambar 10. Grafik luaran arus pada mode pengiriman sinyal kontinyu}

Pada pengujian pengiriman sinyal berdasar permintaan, alat penerima mampu mendapatkan data yang diminta, dan mampu mengeluarkan sinyal arus sesuai dengan data yang didapatkan dari alat pengirim. Waktu yang dibutuhkan berkisar antara 8,6 - 16,2 detik. Grafik luaran arus pada pengujian pengiriman sinyal berdasar permintaan ditunjukkan pada Gambar 11. Rata-rata galat pada pengujian ini adalah 1,004\% span.

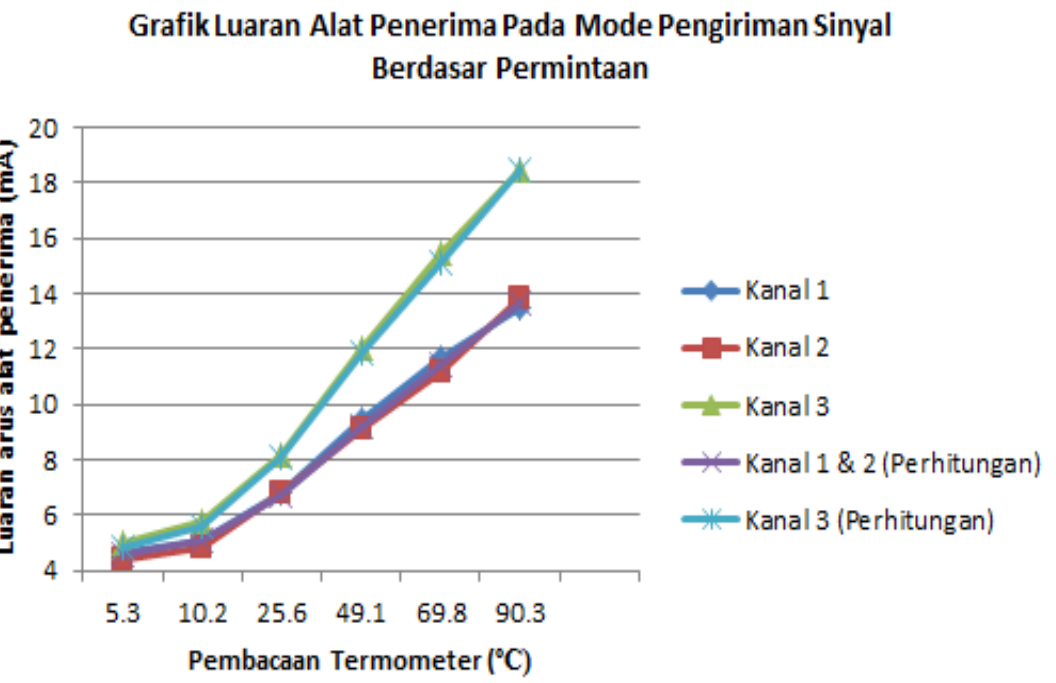

\section{Gambar 11. Grafik luaran arus pada mode pengiriman sinyal berdasarkan permintaan}

Pengujian pengiriman sinyal pada jarak jauh dilakukan dengan jarak alat pengirim dan alat penerima kurang lebih $1000 \mathrm{~km}$. Pada pengujian ini, data yang dikirimkan mampu diterima dengan baik oleh alat penerima. Jauhnya jarak pengiriman tidak terlalu berpengaruh terhadap jeda waktu pengiriman data, yang berkisar antara 6,3 - 15 detik. Grafik luaran arus pada pengujian pengiriman sinyal pada jarak jauh ditunjukkan pada Gambar 12. Rata-rata galat pada pengujian ini adalah $1,013 \%$ span. 


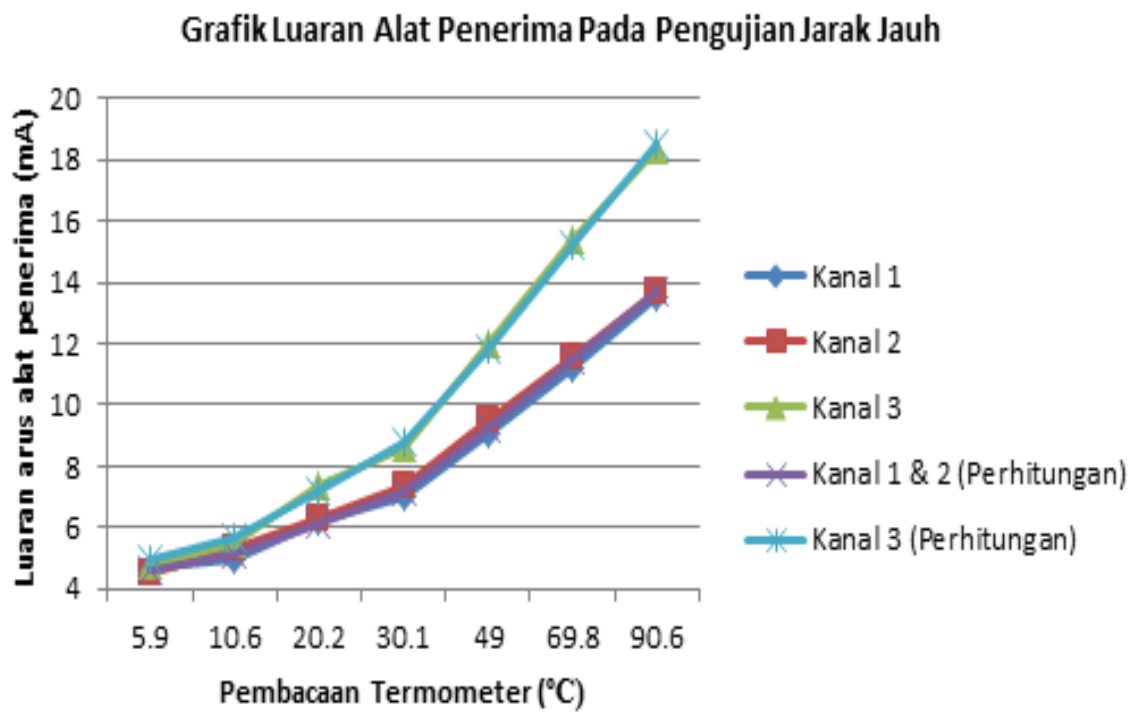

Gambar 12. Grafik luaran arus pada pengiriman sinyal jarak jauh

Pada pengujian pengiriman alarm, relai pada alat penerima mampu bekerja sesuai dengan kondisi alarm pada alat pengirim. Waktu yang diperlukan berkisar $6-8,2$ detik.

\subsection{Pengujian karakteristik alat}

Pada pengujian akurasi, didapatkan nilai simpangan rata-rata adalah 1,0143\% span. Kanal 2 memiliki rata-rata simpangan yang paling kecil. Nilai akurasi alat diperoleh dari nilai simpangan terbesar yaitu 2,5625\% span.

Nilai kelinieran luaran arus ditentukan menggunakan metode terminal-based linearity dengan kurva kalibrasi seperti ditunjukkan pada Gambar 13. Dari hasil pengamatan pada kurva kalibrasi, didapatkan nilai kelinieran $\pm 1,3 \%$ span.

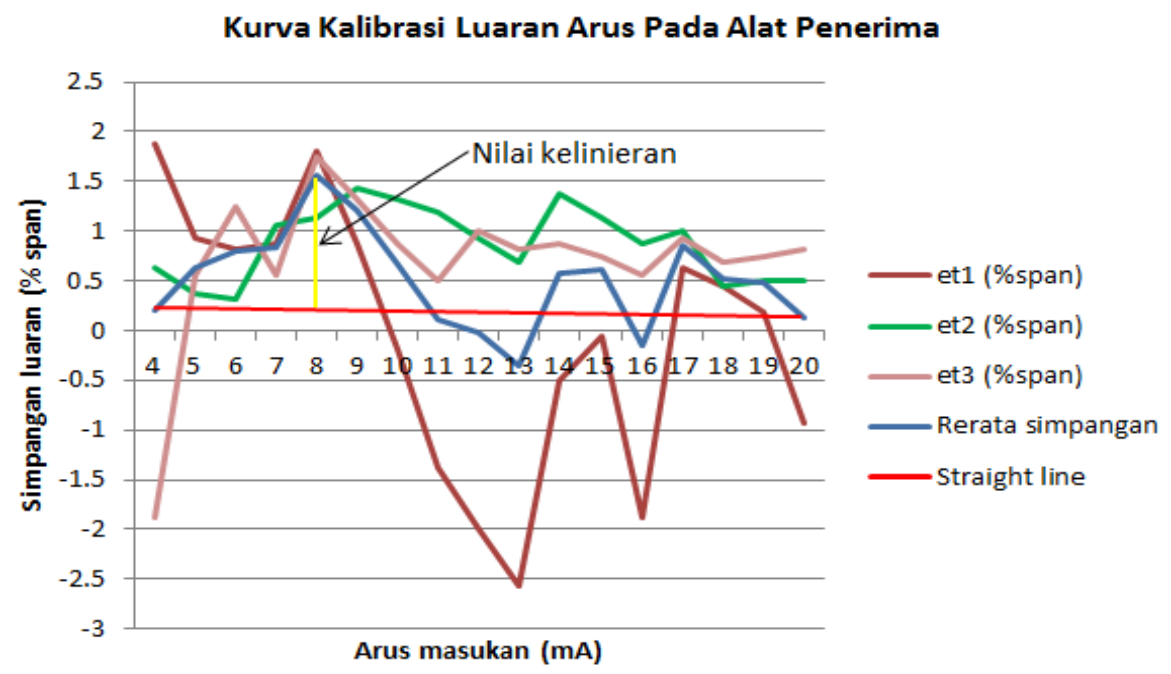

Gambar 13. Kurva kalibrasi luaran arus pada alat penerima

Pengujian presisi dilakukan dengan sampel data yang diambil pada suhu $27^{\circ} \mathrm{C}$ dan $97^{\circ} \mathrm{C}$, dengan 8 kali pengulangan pada masing-masing suhu. Grafik hasil pengujian presisi ditunjukkan pada Gambar 14. 

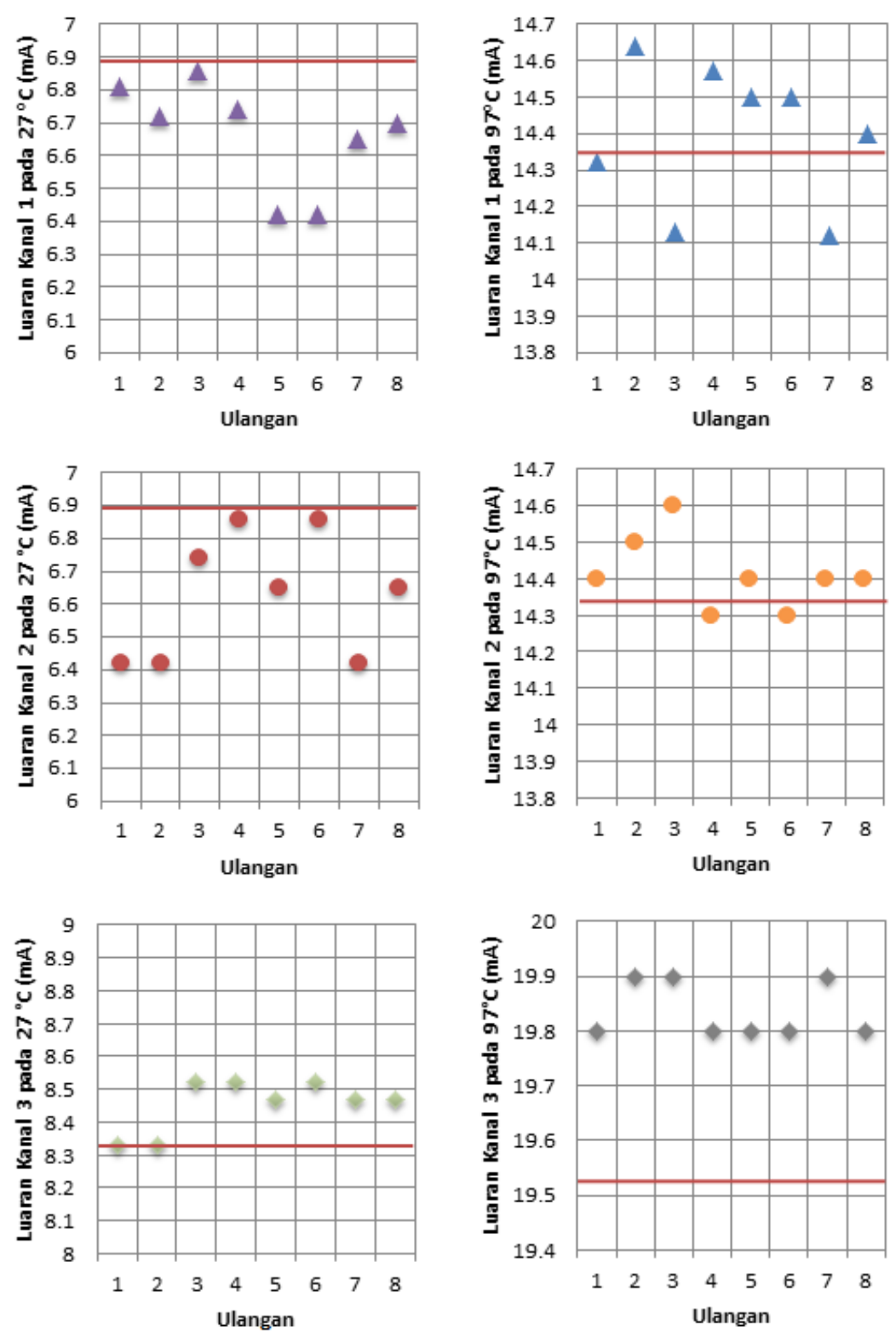

Gambar 14. Grafik hasil pengujian presisi

Nilai presisi merupakan nilai simpangan baku dibagi dengan nilai rata-rata hasil pengukuran. Penghitungan nilai presisi dilakukan dengan menggunakan persamaan berikut.

$$
P=\frac{\sigma}{X} \times 100 \%
$$

dengan $P$ adalah nilai presisi dalam satuan $\%, \sigma$ adalah nilai simpangan baku, dan $X$ adalah nilai rata-rata hasil pengukuran.

Berdasarkan hasil pengamatan, didapatkan nilai rata-rata presisi untuk kanal 1 adalah $1,908 \%$. Nilai rata-rata presisi untuk kanal 2 adalah 1,772\%. Nilai rata-rata presisi untuk kanal 3 adalah 0,603\%. Terlihat bahwa kanal yang paling presisi adalah kanal 3, yang ditunjukkan dengan nilai persentase presisi yang paling kecil. Nilai presisi alat merupakan hasil rata-rata presisi untuk semua kanal yaitu $1,4287 \%$. 


\section{KESIMPULAN}

Adapun kesimpulan yang dapat ditarik berdasarkan hasil penelitian yang telah dilakukan, antara lain:

1. Sistem secara keseluruhan mampu melaksanakan fungsi sebagai pengirim sinyal arus 4$20 \mathrm{~mA}$ dari pemancar suhu dengan jangkauan $0-150{ }^{\circ} \mathrm{C}$ dan $0-100{ }^{\circ} \mathrm{C}$ melalui jaringan GPRS.

2. Jeda waktu yang diperlukan untuk mengirimkan sinyal dari alat pengirim ke alat penerima berkisar antara 4 - 17 detik.

3. Nilai akurasi alat adalah $2,5625 \%$ span, dengan rata-rata simpangan yang paling kecil pada kanal 2, nilai kelinieran alat adalah $\pm 1,3 \%$ span, dan nilai presisi alat pada pengujian dengan sampel suhu $27{ }^{\circ} \mathrm{C}$ dan $97{ }^{\circ} \mathrm{C}$ adalah $1,4287 \%$. Kanal luaran yang paling presisi adalah kanal 3.

\section{DAFTAR RUJUKAN}

Ardianto, H. (1998). Perencanaan dan Pembuatan Pengatur Arus 4-20 mA DC dengan Mikrokontroler 8031 untuk Beban Maksimum 300 Ohm. Surabaya: Tugas Akhir Universitas Petra .

Bangun, A. M. (2014). Arduino for Beginners. Tangerang: Surya University.

Pathoni, T. A. (2008). Pengiriman dan Pengukuran Otomatis Menggunakan Teknologi GPRS. Bandung: Universitas Komputer Indonesia.

Instrument Society of America. (1992). ANSI/ISA-S50.1-1982 ( $R$ 1992): Compatibility of Analog Signals for Electronic Industrial Process Instruments (American Standard). Instrument Society of America.

International Electrotechnical Commision. (1982). IEC 60381: Analogue Signals for Process Control Systems (International Standard). Switzerland: International Electrotechnical Commision.

Kuphaldt; Tony R. (2015). Lessons In Industrial Instrumentation (version 2.11). San Francisco: Creative Commons Attribution 4.0 International Public License.

Parura; Samuel L. B. (2007). Instrumentasi dan Proses Kontrol. Bimbingan Profesi Sarjana Teknik (BPST) Direktorat Pengolahan Angkatan XVII.

Siswanto, T. J. (2008). Perancangan Modul Akuisisi Data dengan Input Output Digital dan Analog. Surabaya: Skripsi Mahasiswa Universitas Petra.

Taub, H; Schilling D. L. (1986). Principles of Communication Systems. Second Edition. Singapore: McGraw-Hill Book Company. 